\title{
The Possibility and Acceptability of Indonesian Traditional Shipping as Feeder Services
}

\author{
Akmal Lazuardy*, Muhammad Helmi, Edy Haryanto \\ Diploma of Naval Architecture Department, Politeknik Negeri Bengkalis, Riau, Indonesia \\ akmal.lazuardy@polbeng.ac.id*,helmi@polbeng.ac.id,edyharyanto@polbeng.ac.id \\ *corresponding author
}

Keywords: $\quad$ Fleet allocation, feeder services, optimization, Pelayaran Rakyat.

\begin{abstract}
A traditional particular marine transport service Pelra (Pelayaran Rakyat) exists in Indonesia. No definite size about this wooden vessel is available but averaging 500 gross tonnages and owned by lower economic community. It has limited payload, speed, as well as operating range. This paper exploits the feasibility and acceptability to use Pelra as feeder service in Indonesia to empower lower economic community and preserve this unique wooden vessel as national heritage. Using linear programming optimization, 3,854 traditional ships are required as national feeder service in Indonesia. The unit cost is \$2.07 per tonnes and may be further reduced to $\$ 1.62$ per tonnes if Pelra boat is able to reduce dwelling time and increase payload as well as the speed.
\end{abstract}

\section{Introduction}

Indonesia is the largest archipelago in the world with a strategic location between Asia and Australia-Oceania. There are five major islands in Indonesia: Sumatera $\left(473,606 \mathrm{~km}^{2}\right)$, Java $\left(132,107 \mathrm{~km}^{2}\right)$, Kalimantan $\left(539,460 \mathrm{~km}^{2}\right)$, Sulawesi $\left(189,216 \mathrm{~km}^{2}\right)$, and Papua $\left(421,981 \mathrm{~km}^{2}\right)$. With more than 17,000 islands and sea makes up two-third of the regional area, marine transportation is the main mode for logistics archipelago [1].

With a vast archipelago area, Indonesia is struggling with high logistics cost accounted for $25 \%$ of Indonesia's Gross Domestic Product (GDP): $12.05 \%$ is transportation cost, $9.47 \%$ is inventory cost, and $4.52 \%$ is the administrative cost. From that composition, 20\% is from marine transportation [2]. Indonesian government through Peraturan Pemerintah No. 17 Tahun 2008 trying to engineer a logistics system based on the hub and spoke network. This program has repeatedly changed its name due to the political regime. At first, it was called Sabuk Nusantara (Archipelago Belt) dividing Indonesia into three logistics route: north, center, and south. Then in 2012, the program became popular under the name Pendulum Nusantara as the government launch economic development plan from 2011 to 2025 called Masterplan Percepatan dan Perluasan Pembangunan Ekonomi Indonesia (MP3EI).

In 2014, together with the newly elected president, the program renamed Tol Laut (Toll of the Sea). With this logistics system, the national GDP will grow to $12.7 \%$ due to the spillover effects of regional development [3]. Although it has changed its name three times, the idea of this program is 
still the same: select five hub ports, 19 feeder ports, and use 3,500 TEUs liner shipping that sails from west to east and vice versa like a pendulum. Liner shipping which serves pendulum routes is not for container ship only, but also for passenger, agricultural commodities, and mineral products [4]. However, there are already traditional shipping services named Pelayaran Rakyat or Pelra.

Pelra is a marine transportation services with up to 500 gross tonnages (GT) cultivated by lower economic class using traditional wooden vessel hence have limited technical capacity and operating range. The business pattern usually derived from local tribe e.g. Bugis, Madurese, and Butonese [5]. Pelra was vital in the eastern region as its operational scheme reach the most remote areas in Indonesia [6]. From 2001 to 2005, there are 2,530 units of Pelra [7]. However, in 2013 there were only 1,340 units with low productivity: 18.6 tons per GT annually as it only transported low-value cargo: plantation crops, break-bulk cargo, general cargo, and passengers from outlying areas [5].

Due to the low number of commodities being transported, Pelra has significant proportions of logistics cost [1]. The competition with the modern ship is inevitable and Pelra is struggling to cope because of its traditional scheme. Although Pelra setbacks already began in 1988 when the government opened more than 137 ports for foreign ships; the effect still echoed until today as Pelra only handles 5\% from total domestic cargo [5]. Pelra ship design, management pattern, and shipbuilding technique should consider as a national heritage and preserve it from extinction. This research tries to exploit the possibility to use Pelra as feeder service in Pendulum Nusantara as a solution for this problem.

\section{Methodology}

The ultimate research question for this research is whether Pelra is acceptable as feeder service in Pendulum Nusantara to preserve it from extinction. This issue might extend to other issues: is the existing fleet capable for this role? And if it is not, how many units are required complying for this role? And to answer those questions, linear programming is used to solve Pelra optimized fleet number with certain limitations.

Linear programming is deterministic, no random input variables, a mathematical modeling technique that used to optimize the use of limited resources [8]. First introduced by George Dantzig in 1947, the linear programming model has been widely applied in many fields such as mining, transportation, education, and banking [9]. The linear programming model consists of three primary elements: decision variables (the value that seeks to determine), the objective function (aim to optimize), and constraint that need to satisfy.

Between lowest and higher value there is an area called feasible region where all value inside it meet the linear programming model either maximization or minimization. In this research, the decision variable is Pelra fleet number to fulfil its role as feeder service. The objective function is to minimize total transport cost, i.e. capital, operational, voyage, and cargo handling cost. There are three constraints on this research. First, cargo supplied to feeder ports must have the same value or less than the hub supply capacity. Second, the cargo provided should have the same value or greater than the demand. If oversupplied, penalty cost is added to the total cost of compensation. Lastly, the fleet frequency should not exceed the maximum frequency available. The optimization process was carried out by using Microsoft Excel Solver Add-Ins.

This research conducted on five hub ports: Belawan, Tanjung Priok, Tanjung Perak, Makassar, and Sorong. Each hub port creates a loop consist of 3 to 5 feeder ports that have economic distance from its respective hub ports, i.e. 412 nautical miles [10]. Optimization process uses four type of Pelra vessel, which is 100, 200, 300, and 400 GT. As hub liner service in Pendulum Nusantara is modern shipping, it requires transshipment to move cargo from modern fleet into the smaller traditional ship. Although this intermodality is an interesting subject to study, this research would 
compensate this problem with added one day in dwelling time calculation. In cost calculation, the currency applied in this research is the US Dollar (USD) but in some raw data using Rupiah (IDR) as its original currency. All the information used ranges between 2010 and 2016 as some of 2017 data is not published yet.

\section{Data Collection Analysis}

\subsection{Existing Conditions}

Traditional shipping in Indonesia is on the verge of failing as Pelra is unable to compete with modern shipping. Recorded in 2010, the number of Pelra fleet amounted to 1,301 units while modern shipping reached 294,217 units [11]. In the same year, Pelra is only able to transport 13,474,765 tons while modern shipping accounts for 269 million tons or 5\% from total domestic cargo [5]. By using an exponential smoothing technique, the number of Pelra ships in 2017 accounts for 1,368 units and transport 26,249,501 tons.

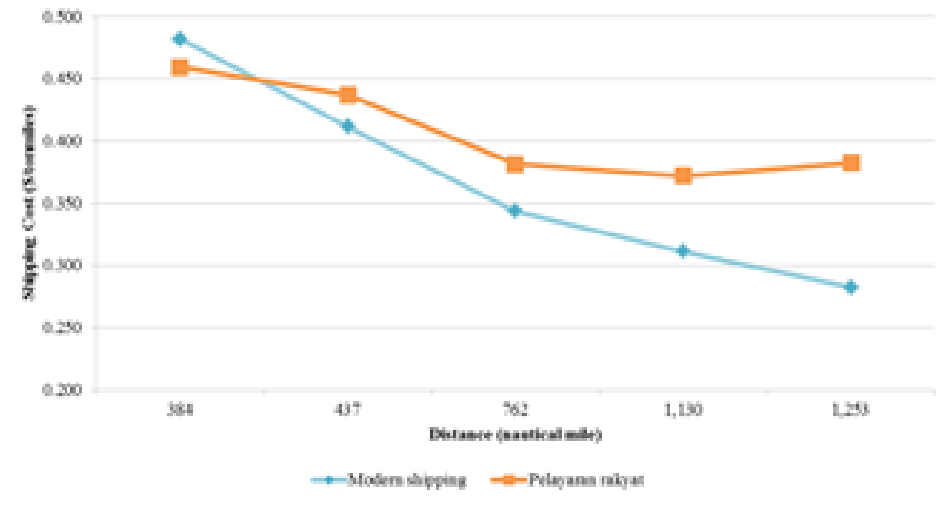

Figure 1: Shipping cost comparison.

At first glance, modern shipping is superior and outperformed Pelra in any aspects. However, Pelra has two comparative advantages against modern shipping. First, Pelra has a small draught and easy for them to enter into a far-flung water body, e.g. river and estuary. With 3 meters average draught, Pelra able to reach 26 out of 27 feeder ports in Pendulum Nusantara plan. Handy container and small general cargo ship only cover 20 and 22 feeder ports respectively due to its deeper draught. The second advantage is lower shipping cost up to 412 nautical miles [10]. At the distance of 384 nautical miles, which equal as the distance between Tanjung Priok and Tanjung Perak, Pelra has lower shipping cost with $\$ 0.459 /$ tonmiles. With the same length, modern shipping amounted $\$ 0.482 /$ tonmiles. However, in 1,253 nautical miles or equal to the distance between Tanjung Perak and Sorong, modern shipping has very significant lower cost: $\$ 0.282 /$ tonmiles while Pelra itself only amounted to $\$ 0.383 /$ tonmiles. The intersection of those two trend line is in 412 nautical miles with $\$ 0.439 /$ tonmiles as critical unit cost (Figure 1).

Based on those comparative advantages, Pelra is suitable as feeder service but limited to feeder ports in economic distance from the nearest hub port (Table 1). There are seven feeder ports that are far from any hub port: Jambi (487 nm from Tanjung Priok), Jayapura (655 nm from Sorong), Merauke (914 nm from Sorong), Pontianak (420 nm from Tanjung Priok), Tarakan (556 nm from Makassar), Teluk Bayur (550 nm from Tanjung Priok), and Tenau (635 nm from Makassar). According to those grouping, Batulicin, Lembar, and Tanjung Emas have close distance from two hub ports. For simplification, those three are under nearest hub port only. 
Table 1: Feeder ports grouping.

\begin{tabular}{|c|c|c|}
\hline Loops & Feeder ports & Distance from hub (nm) \\
\hline \multirow{4}{*}{ Belawan loop } & Batu Ampar & 373 \\
\hline & Dumai & 211 \\
\hline & Kuala Tanjung & 59 \\
\hline & Malahayati & 252 \\
\hline \multirow{4}{*}{$\begin{array}{l}\text { Tanjung Priok } \\
\text { loop }\end{array}$} & Palembang & 355 \\
\hline & Pangkal Balam & 289 \\
\hline & Panjang & 142 \\
\hline & Tanjung Intan & 388 \\
\hline \multirow{4}{*}{$\begin{array}{c}\text { Tanjung Perak } \\
\text { loop }\end{array}$} & Kumai & 327 \\
\hline & Lembar & 267 \\
\hline & Sampit & 360 \\
\hline & Tanjung Emas & 167 \\
\hline \multirow{5}{*}{ Makassar loop } & Batulicin & 279 \\
\hline & Kariangau & 292 \\
\hline & Kendari & 345 \\
\hline & Palaran & 331 \\
\hline & Pantoloan & 287 \\
\hline \multirow{3}{*}{ Sorong loop } & Ambon & 275 \\
\hline & Bitung & 406 \\
\hline & Ternate & 290 \\
\hline
\end{tabular}

\subsection{Cargo Flow and Cost Calculation}

Each hub port can handle cargo flow up to a certain amount. This value is regarded as the supply capacity of the port. The amount of supply to feeder ports will never exceed that capacity. For example, Tanjung Priok left four hub ports behind with capacity reaches 33,828,878,092 tonmiles in 2014 [11]. The closest competitor is Tanjung Perak, which is only has a capacity 5,783,534,944 tonmiles in the same year. As Jakarta is the capital city of Indonesia and many industries located in Jakarta, it is not a surprise if Tanjung Priok has the highest capacity. However, higher supply capacity in Jakarta alone is a major problem in Indonesia. It is necessary to distribute local economic zone outside Java to strengthen the national economy.

As Pelra ship divided into four different size variations, its transportability is also different. The small sized ship has small cargo to transport annually. For $100 \mathrm{GT}$, it is around 3 thousand tons per year with the exception for Kuala Tanjung which stand out with 6.49 thousand per year. 400 GT ship can carry cargo up to 16 thousand tons per year (Table 2).

Shipping cost divided into four types: capital cost, operational cost, voyage cost, and cargo handling cost. Capital cost consists of traditional ship price and converted into charter rate per day. Operational cost consists of crew salary, storage and provision, lubricants, insurance, administration, repair, and maintenance.

Voyage cost mainly divided into main engine fuel oil, auxiliary engine diesel oil, feeder port charges, and hub port tariffs. Lastly, cargo handling cost consists of handling charges in feeder and hub ports as well as inland transport services. To sum up, capital cost has higher proportion as iron wood prices is very expensive.

Cargo handling cost and voyage cost comes in second and third position respectively due to inland transport cost and higher port tariff either in feeder ports and hub ports. However, because of family-related management and traditional managing company, operational cost has smallest 
proportions although has significant amount of insurance cost due to high risk-cost per cargo (Figure 2).

Table 2: Supplied cargo for each size.

\begin{tabular}{|l|r|r|r|r|}
\hline \multirow{2}{*}{ Feeder ports } & \multicolumn{4}{|c|}{ Cargo transported (thousand tonnes per year) } \\
\cline { 2 - 5 } & \multicolumn{1}{|c|}{$100 \mathrm{GT}$} & \multicolumn{1}{c|}{ 200 GT } & \multicolumn{1}{c|}{$300 \mathrm{GT}$} & \multicolumn{1}{c|}{$400 \mathrm{GT}$} \\
\hline Batu Ampar & 2.87 & 6.03 & 8.60 & 10.25 \\
\hline Dumai & 4.37 & 8.75 & 12.22 & 13.87 \\
\hline Kuala Tanjung & 6.49 & 10.25 & 13.12 & 15.08 \\
\hline Malahayati & 3.77 & 8.14 & 11.31 & 13.27 \\
\hline Palembang & 3.32 & 6.94 & 10.41 & 13.27 \\
\hline Pangkal Balam & 3.47 & 6.94 & 9.95 & 11.46 \\
\hline Panjang & 5.13 & 9.35 & 12.22 & 15.08 \\
\hline Tanjung Intan & 3.32 & 6.64 & 9.95 & 12.06 \\
\hline Kumai & 3.47 & 8.14 & 12.22 & 15.08 \\
\hline Lembar & 4.07 & 8.75 & 13.12 & 16.29 \\
\hline Sampit & 3.32 & 6.94 & 11.31 & 13.27 \\
\hline Tanjung Emas & 5.13 & 9.35 & 13.12 & 16.29 \\
\hline Batulicin & 3.77 & 7.54 & 10.41 & 12.06 \\
\hline Kariangau & 3.47 & 6.94 & 10.41 & 10.86 \\
\hline Kendari & 3.32 & 6.64 & 9.95 & 10.86 \\
\hline Palaran & 3.32 & 6.64 & 9.05 & 10.25 \\
\hline Pantoloan & 3.47 & 7.54 & 11.31 & 12.06 \\
\hline Ambon & 3.77 & 7.54 & 10.41 & 11.46 \\
\hline Bitung & 3.02 & 6.94 & 10.41 & 12.06 \\
\hline Ternate & 3.32 & 6.64 & 9.05 & 10.25 \\
\hline
\end{tabular}

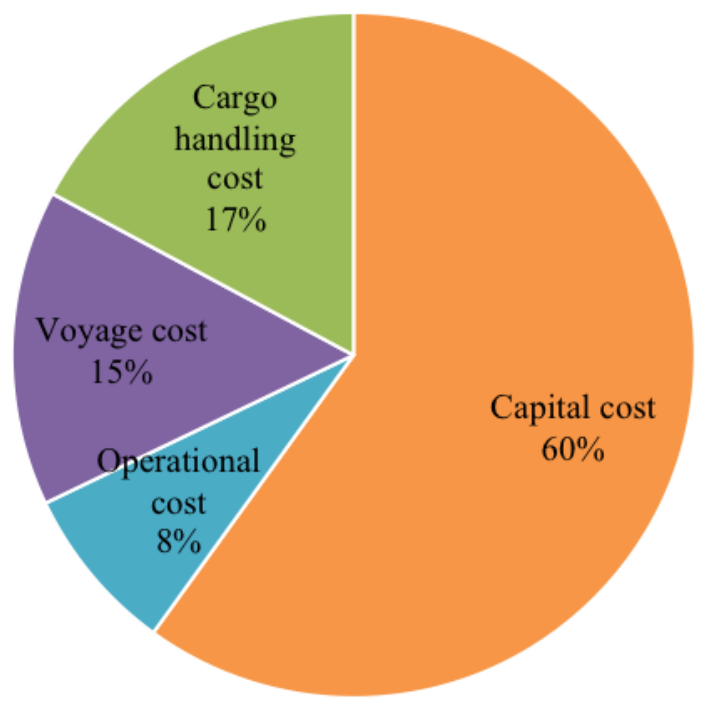

Figure 2: Traditional shipping cost proportions.

By calculating transport cost per tons, using large ships can make the cost cheaper. However, not too big that will make diseconomies. Diseconomies of scale discovered on all routes except Palembang. The vessel above 400 GT may be assigned because the cargo in that route is still a lot and make economies of scale possible for the larger ship. On the other hand, Kuala Tanjung is 
already diseconomies with 100 GT hence it may be suitable to assign smaller ship for this route. In summary, Pelra can reduce transport cost with 300 GT as 400 GT is diseconomies in majority maps.

Table 3: Traditional ship transportation cost.

\begin{tabular}{|c|c|c|c|c|}
\hline \multirow{2}{*}{ Feeder ports } & \multicolumn{4}{|c|}{ Transport cost (\$/tonnes) } \\
\hline & $100 \mathrm{GT}$ & $200 \mathrm{GT}$ & $300 \mathrm{GT}$ & $400 \mathrm{GT}$ \\
\hline Batu Ampar & 5.09 & 3.30 & 3.08 & 3.38 \\
\hline Dumai & 2.29 & 1.67 & 1.63 & 1.98 \\
\hline Kuala Tanjung & 1.05 & 1.18 & 1.35 & 1.63 \\
\hline Malahayati & 3.07 & 1.94 & 1.91 & 1.98 \\
\hline Palembang & 4.00 & 2.62 & 2.22 & 2.21 \\
\hline Pangkal Balam & 3.56 & 2.56 & 2.38 & 2.79 \\
\hline Panjang & 1.66 & 1.42 & 1.58 & 1.67 \\
\hline Tanjung Intan & 4.02 & 2.92 & 2.49 & 2.60 \\
\hline Kumai & 3.60 & 1.97 & 1.72 & 1.77 \\
\hline Lembar & 2.68 & 1.70 & 1.48 & 1.52 \\
\hline Sampit & 4.00 & 2.62 & 1.95 & 2.21 \\
\hline Tanjung Emas & 1.67 & 1.46 & 1.43 & 1.46 \\
\hline Batulicin & 3.08 & 2.26 & 2.18 & 3.08 \\
\hline Kariangau & 3.57 & 2.58 & 2.18 & 3.08 \\
\hline Kendari & 3.97 & 2.88 & 2.45 & 3.08 \\
\hline Palaran & 3.97 & 2.88 & 2.81 & 3.39 \\
\hline Pantoloan & 3.57 & 2.26 & 1.91 & 2.56 \\
\hline Ambon & 3.07 & 2.22 & 2.19 & 2.75 \\
\hline Bitung & 4.68 & 2.69 & 2.30 & 2.63 \\
\hline Ternate & 3.92 & 2.83 & 2.76 & 3.53 \\
\hline
\end{tabular}

\section{Result and Discussions}

\subsection{Spreadsheet Optimization}

This research uses Microsoft Excel spreadsheet with the Solver Add-Ins to make the model. There are three essential elements in the optimization: decision variables, objective function, and constraints. As mentioned before, the decision variables are required fleet from four different ship sizes: 100, 200, 300, and $400 \mathrm{GT}$ as well as from 20 different routes. The decision variables will vary according to the number of iterations required to satisfy the objective function. Every value of decision variables creates different values of the objective function. The solver will iterate until the objective function obtained and satisfy all the constraints.

The objective function is the variable that sought in an optimization phase. In this research, the objective function is the minimization of transport cost. It is the sum of capital, operational, voyage, and cargo handling cost as well as imposed nationally in operating such some optimized fleet. Penalty cost added to the objective function if the cargo supplied exceeds the demand on each route. 
Penalty cost in this research assumed as $\$ 10 /$ tonmiles. The objective function should be in integer number as there is no such thing as 5.25 units even if the demand is satisfied with this figure. Therefore, this research would be round this number up as it would be appropriate if employ six units instead of 5.25 units. The objective function in this study formulated as follows:

$$
\min f(x)=[\Sigma \text { Total cost } k+\text { Penalty cost }]
$$

There are five constraints for this optimization model, two regarding its node, one regarding the network, and two regarding the ship. First, cargo supplied to feeder ports must have the same value or less than the hub supply capacity. This is the level of loading and unloading cargo within the network. From Pendulum Nusantara logistics concept, hub ports only served by another hub hence this number is indicating hub ports capability to supply respective feeder ports within its loop. For each $1 \leqslant \mathrm{i} \leqslant 5$ is an integer; then it formulated as:

RTPA : Round trip per annum (times)

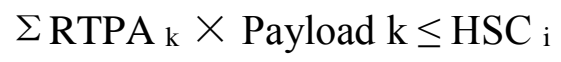

HSC : Hub supply capacity (tonmiles)

$\mathrm{n}$ : The amount of feeder ports in hub port $\mathrm{i} ; 3 \leq \mathrm{n} \leq 5$

$\mathrm{k}$ : Feeder routes

Cargo supplied is calculated from multiplying Round Trip per Annum (RTPA) with the payload. On the other hand, hub supply capacity data obtained from [11] with additional forecast analysis until 2016. Special case for Sorong loop, supply capacity added from other ports in Papua as it would be very low if use Sorong capacity alone.

$$
\sum \text { RTPA }_{\mathrm{k}} \times \text { Payload } \mathrm{k} \geq \mathrm{D}_{\mathrm{k}}
$$

D : Demand (tonmiles)

The second constraint is the cargo provided should have the same value or greater than the demand in each feeder ports. If the load supplied is greater than demand, penalty cost incurred to total transport cost as depicted in (1). The demand data obtained from the same source as hub supply capacity, specifically for domestic cargo flow in feeder ports area. The (2) and (3) are limiting optimization value in its nodes, both in hub and feeder ports.

The third constraint is regarding its network, which the fleet frequency should not be greater than the maximum frequency available. Maximum frequency obtained by averaging RTPA in each route for each size. This can be further expressed as:

$$
\sum \text { RTPA }_{\mathrm{k}} \times \mathrm{S} \mathrm{k} \leq \mathrm{MF}_{\mathrm{k}}
$$

$S$ : Optimized number of ship for each size (unit)

$\mathrm{MF}$ : Maximum frequency (times)

The fourth constraint is regarding its ship, which the cargo supplied from the feeder ports should be less than the hub shipping service or the hub liner vessel capacity to accommodate cargo transfer within network. The hub liner services will sail within its own loops hence it become maximum transport capacity to serve feeder ports in their respective loops. This can be expressed as:

$$
\sum \text { RTPA }_{\mathrm{k}} \times \text { Payload }_{\mathrm{k}} \leq \text { Liner capacity }_{\mathrm{i}}
$$

$\mathrm{n}$ : The amount of feeder ports in hub port $\mathrm{i} ; 3 \leqslant \mathrm{n} \leqslant 5$ 
The fifth and last constraint is regarding its ship as well, which the Pelra unit cost should be less than the steel ship unit cost. This constraint must be addressed as Pelra and modern ship in competition to become feeder service. The value of Pelra unit cost should be smaller than its competitor to justify their acceptability as feeder services. This can be expressed as:

$$
\mathrm{UC}_{\mathrm{p}} \times \mathrm{D}_{\mathrm{k}} \leq \mathrm{UC}_{\mathrm{s}} \times \mathrm{D}_{\mathrm{k}}
$$

UCp : Pelra unit cost (\$/tonnes)

UCs : Steel ship unit cost (\$/tonnes)

$\mathrm{D}$ : Reciprocal distance within hub loops (nm)

$\mathrm{k}$ : Feeder routes

The solver will iterate to find the most optimal option after selecting the objective function, add all the constraints, as well as its decision variables. It turns out that the fleet number required for Pelra to become feeder service is 3,858 units (Table 2). Most of them are $300 \mathrm{GT}$ and $400 \mathrm{GT}$. It is logical because bigger ships have economies of scale ability. The larger it ship, the lower cost incurred. However, 200 GT ship may suit for Kuala Tanjung, Panjang, Kariangau, and Kendari where the demand is low. Optimization result shows that there is one route using 100 GT ship but only served by one unit Pelra ship. Transport cost for this optimized fleet is $\$ 87,528,130$ per year. Notice that this cost is actually for national scale if Pelra used as feeder service in Indonesia. Penalty cost is incurred in three feeder ports: Kariangau, Kendari, and Palaran as demand in feeder ports is exceeded by cargo supply. Also, optimization result indicates that the unit cost become subtle: $\$ 2.08$ per tons.

Belawan loop specifically needs 588 units. Tanjung Priok has the highest units $(1,223)$ to satisfy high demand in Java. However, it is not applicable with Tanjung Perak that requires only 790 units despite the fact that it is located in Java as well. Makassar loop, with high government initiatives to spread more economic zones outside Java, ended up with 1.000 units. Sorong, with weak demand, only satisfied with 257 units. The forecasting analysis in the earlier mentioned that Pelra fleet would be as many as 1,368 units in 2017. However, this optimization suggests that 3,858 units are needed to become feeder service. It is $65 \%$ more than 2017 units fleet to match with the optimized result.

Another discouraging fact is modern shipping will have 350,975 units in the same year [11]. That is $1.10 \%$ against Pelra optimized result. However, this number is better than using existing Pelra ship (1,368 units), which is accounted for $0.39 \%$ only. To sum up, the possibility to use Pelra as feeder services is wide open but its acceptability is unlikely as they cannot cover required fleet to become feeder service right now.

\subsection{Sensitivity Analysis}

There are three sensitivity analyses to test how elastic the optimized result in varying variables: dwelling time, load factor, and ship speed. Without dwelling time ( 0 days), the number of ships slightly decreased to 3,451 units with unit cost $\$ 1.62$ per tons. In the three days dwelling time, the number of ships increased profoundly to 4,722 units with a higher unit cost: $\$ 3.12$ per tons (Fig. 2). Optimization did not find any feasible solution if dwelling time is more than three days. Dwelling time affect the fleet allocation as it influences the port time. The higher the port time, the higher fleet number is required to satisfy constant demand.

The number of ships is increased sharply to 48,290 units in 5\% load factor with $\$ 13.33$ per tons. However, in $95 \%$ load factor the number of vessels dropped to 3,700 units with a low unit cost: 
$\$ 2.00$ per tons. The graph is not typically decreased in a consistent manner, but rather has elastic shape with a critical point in $45 \%$ load factor (Fig. 3). In other words, the number of ships and its unit cost is not drastically increased as long as keeping its load factor above $45 \%$. Load factor affects the unit cost as the cost divided by cargo transported. Therefore, the higher load factor, the greater cargo transported, and this makes the unit cost lower.

Table 4: Optimization result.

\begin{tabular}{|c|c|c|c|c|c|}
\hline \multirow{2}{*}{ Loops } & \multirow{2}{*}{ Feeder ports } & \multicolumn{4}{|c|}{ Round up fleet required (units) } \\
\hline & & $100 \mathrm{GT}$ & $200 \mathrm{GT}$ & $300 \mathrm{GT}$ & $400 \mathrm{GT}$ \\
\hline \multirow{4}{*}{ Belawan loop } & Batu Ampar & - & - & 114 & - \\
\hline & Dumai & - & - & 289 & - \\
\hline & Kuala Tanjung & - & 27 & 7 & - \\
\hline & Malahayati & - & - & 151 & - \\
\hline \multirow{4}{*}{ Tanjung Priok loop } & Palembang & - & - & - & 108 \\
\hline & Pangkal Balam & - & - & 110 & - \\
\hline & Panjang & - & 301 & 101 & - \\
\hline & Tanjung Intan & - & - & 603 & - \\
\hline \multirow{4}{*}{ Tanjung Perak loop } & Kumai & - & - & 87 & 87 \\
\hline & Lembar & - & - & 16 & 16 \\
\hline & Sampit & - & - & 60 & 119 \\
\hline & Tanjung Emas & - & - & 405 & - \\
\hline \multirow{5}{*}{ Makassar loop } & Batulicin & - & - & 202 & - \\
\hline & Kariangau & - & 1 & 231 & 58 \\
\hline & Kendari & 1 & 1 & 98 & 33 \\
\hline & Palaran & - & - & 350 & 1 \\
\hline & Pantoloan & - & - & 19 & 5 \\
\hline \multirow{3}{*}{ Sorong loop } & Ambon & - & - & 89 & - \\
\hline & Bitung & - & - & 74 & 37 \\
\hline & Ternate & - & - & 57 & - \\
\hline
\end{tabular}

When it decreased by 1 knot, optimized fleet become 4,143 units with $\$ 3.03$ per tons. This number is declining as the speed increase. If it rose by 1 knot, fleet allocation decreased to 3,900 units, and unit cost fell into $\$ 1.70$ per tons (Fig. 4). The speed affect the unit cost as the faster ships make more RTPA and have less port time hence have lower port charges and cargo-handling cost would decrease per tons even in the higher speed the needs of fuel is greater because of high fuel consumption at top speed.

From those three analyses, Pelra may reduce its unit cost by not exceeding three days dwelling time, keeping load factor above $45 \%$, and increase its speed. Unit cost only inelastic if drop below $45 \%$ load factor hence as long as it above $45 \%$ the unit cost is relatively small. More dwelling time makes the higher unit cost, and faster ship makes the lower unit cost as well. But, Pelra would benefit more if keeping dwelling time as little as possible. It is because of the sensitivity gradient from dwelling time is 0.5028 , while speed sensitivity has 0.1429 only.

\section{Conclusions}

Total optimized fleet as much as 3,858 units are still massive compared to the existing fleet, which amounted to 1,368 units in 2017. That is $65 \%$ more than existing fleet for Pelra to become national feeder service. The unit cost is low with $\$ 2.07$ per tonnes and may further reduce to $\$ 1.62$ per tonnes during sensitivity analysis if PELRA able to minimize dwelling time, maximize its payload, and increase ship's speed. 


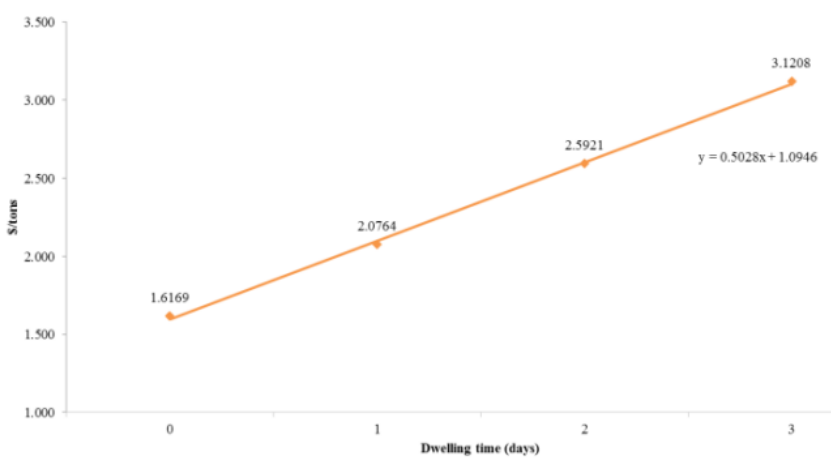

Figure 3: Dwelling time sensitivity.

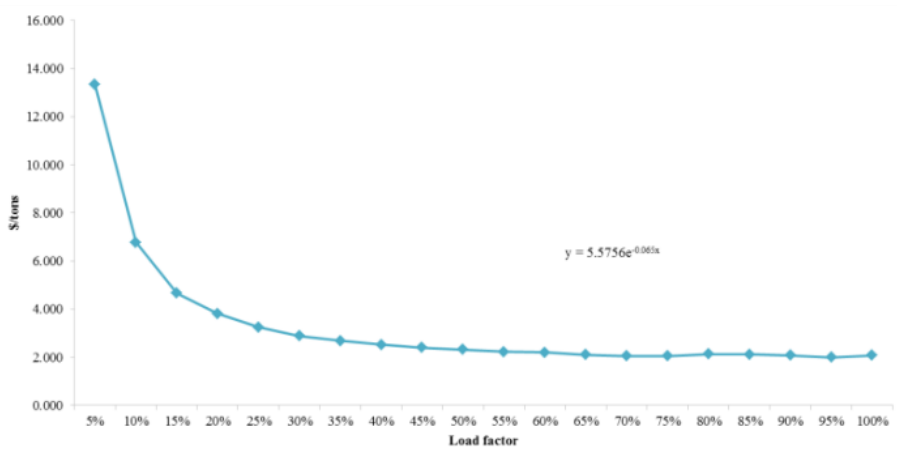

Figure 4: Load factor sensitivity.

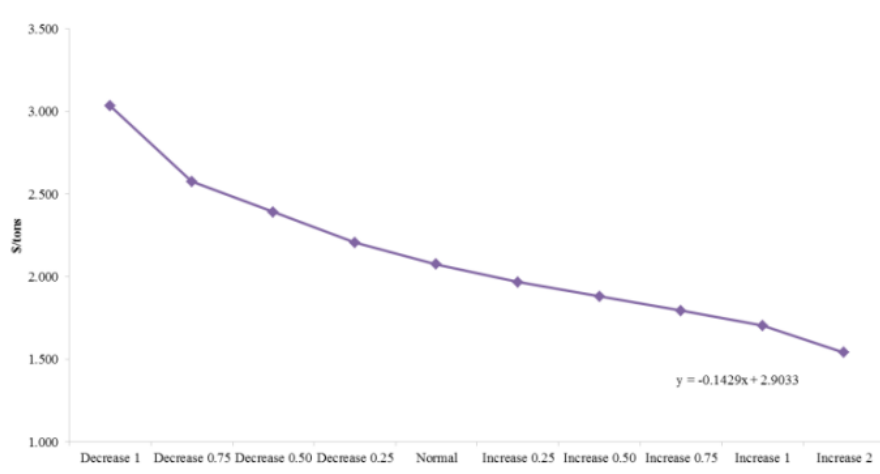

Figure 5: Speed sensitivity. 


\section{Acknowledgements}

Special thanks to Pusat Penelitian dan Pengabdian Masyarakat Politeknik Negeri Bengkalis for its financial support under PNBP Research Funding during this research until its dissemination process.

\section{References}

[1] Pujawan, N., Arief, M.M., Tjahjono, B. and Kritchanchai, D., an Integrated Shipment Planning and Storage Capacity Decision under Uncertainty, International Journal of Physical Distribution and Logistics Management. 45/9/10 (2015) 913-937.

[2] Direktorat Jenderal Perhubungan Laut, Rencana Strategis Direktorat Jenderal Perhubungan Laut Tahun $2015-$ 2019. Jakarta, Indonesia: Kementerian Perhubungan Republik Indonesia, 2015.

[3] Kementerian Koordinator Bidang Perekenomian, Masterplan Percepatan dan Perluasan Pembangunan Ekonomi Indonesia 2011-2025. Jakarta, Indonesia: Kementerian Koodinator Bidang Perekonomian, 2011.

[4] Prihartono, B., Pengembangan Tol Laut Dalam RPJMN 2015-2019 dan Implementasi 2015. Badan Perencanaan Pembangunan Nasional [PowerPoint Presentations]. 110 (2015).

[5] Karana, S., Armada Pelayaran Rakyat Sebagai Sarana Transportasi Angkutan Antar Pulau Dalam Era Pasar Bebas, Jurnal Alami 8/3 (2003) 50-56.

[6] Hermanto, A.W., Eksistensi Transportasi Laut Pada Pelayaran Rakyat, Jurnal Teknik Sipil \& Perencanaan, 12/1 (2010) 71-78.

[7] Asmiati, Jinca, Y.M. and Alam, S., Business Management of Traditional Shipping. Universitas Hasanuddin, 2015.

[8] Taha, H.A., Operations Research: An Introduction. 9th ed., International ed. Boston, Mass., 2011.

[9] Winston, W.L., Operations Research: Applications and Algorithms. 3rd ed, Belmont, Calif. Duxbury Press, 1994.

[10] Lazuardy, A., Studi Perbandingan Layanan Transportasi Laut; Studi Kasus Pelayaran Rakyat dan Pelayaran Nasional. Institut Teknologi Sepuluh Nopember, Surabaya., 2015.

[11] Badan Pusat Statistik, Statistik Transportasi Laut. Badan Pusat Statistik Indonesia,2014 